\title{
Evaluation of palpebral fissure and orbital volume after bimatoprost $0.03 \%$ orbital injections. Experimental study in rats
}

\author{
Avaliação da fenda palpebral e do volume orbitário \\ após aplicações orbitárias de bimatoprost 0,03\%. \\ Estudo experimental em ratos
}

Nilson Lopes da Fonseca Junior ${ }^{1}$, Giuliana Petri², Juliana Mora Veridiano ${ }^{3}$, José Ricardo Carvalho Lima Rehder ${ }^{4}$

\begin{abstract}
Objective: To evaluate in experimental animals the changes of the palpebral fissure and the orbital volume after orbital injection of bimatoprost $0.03 \%$. Methods: Two main groups of Wistar rats were analyzed, one after orbital injection of bimatoprost $0.03 \%$ and another, a control group, after orbital injection of saline solution. The calculation of the palpebral fissure was done on images by means of computer processing, using the program Image J. After taking photographs, the animals were submitted to bilateral orbital exenteration and the volume was calculated in all the animals by the water displacement method (Archimedes' Principle). Results: While comparing the measurements of the palpebral fissure and the orbital volume among animals given an injection with bimatoprost $0.03 \%$ and the control group it was found that there were no statistically significant differences. Conclusion: In this study there were no statistically significant differences in the measurement of the vertical palpebral fissure and the orbital volume among animals given the orbital injection of bimatoprost $0.03 \%$ and the animals of the control group.
\end{abstract}

Keywords: Synthetic prostaglandins F/therapeutic use; Synthetic prostaglandins F/adverse effects

\section{RESUMO}

Objetivo: Avaliar em modelos experimentais as alterações da fenda palpebral e do volume orbitário após aplicação orbitária de bimatoprost $0,03 \%$. Métodos: Dois principais grupos compostos por ratos Wistar foram analisados, sendo comparados os animais submetidos à injeção orbitária de bimatoprost $0.03 \%$ com os submetidos à injeção orbitária de solução salina. $\mathrm{O}$ cálculo da fenda palpebral vertical foi obtido através de imagem computadorizada utilizando-se o programa Image J. Após serem fotografados os animais foram submetidos à exenteração bilateral e o volume orbitário foi calculado pelo método de deslocamento da coluna de água (Princípio de Archimedes). Resultados: Quando foram comparadas as medidas da fenda palpebral vertical e do volume orbitário entre os animais submetidos a injeção de bimatoprost $0.03 \%$ e o grupo controle não foi obsevada diferença estatisticamente significante. Conclusão: Neste estudo não houve diferença estatisticamente significante nas medidas da fenda palpebral vertical e no volume orbitário entre os animais submetidos à injeção orbitária de bimatoprost $0.03 \%$ e o grupo controle.

Descritores: Prostaglandina F sintética/uso terapêutico; Prostaglandina F sintética/efeitos adversos

\footnotetext{
'Faculdade de Medicina do ABC, Santo André (SP), Brazil;

${ }^{2,3,4}$ Animal Laboratory House, Faculdade de Medicina do ABC, Santo André (SP), Brazil;
}

Study carried out at Faculdade de Medicina do ABC, Santo André (SP), Brazil.

The authors declare no conflicts of interest.

Recebido para publicação em 23/3/2014 - Aceito para publicação em 8/9/2014 


\section{INTRODUCTION}

$\mathbf{T}$ he bimatoprost $0.03 \%$ solution is a prostamide analog with a potent ocular hypotensive effect. It is a synthetic prostaglandin F2Ü (PGF2 $)$ analog ${ }^{[1,2]}$, which reduces intraocular pressure (IOP) in humans, as it increases the uveoscleral or nonconventional outflow of the aqueous humor ${ }^{[3]}$. Bimatoprost is commonly used as a first-choice drug in the treatment of primary open-angle glaucoma and is, generally, well tolerated ${ }^{[4]}$.

Clinical studies reported adverse effects in 15 to $45 \%$ of patients who received daily single doses over a three month period. In a decreasing order of incidences, the most common adverse effects observed were: conjunctival hyperemia, eyelash growth, itching of the eyes, dry eyes, burning eyes, sensation of having something in the eye, eye pain, palpebral erythema, periocular skin pigmentation, eye irritation, ocular secretion, asthenopia, allergic conjunctivitis, watery eyes, superficial punctate keratitis, photophobia, intraocular inflammation (i.e., iritis and iris pigmentation), changes in liver function tests, infections (especially colds and respiratory tract infections) and macular edema, including cystoid macular edema ${ }^{[5-8]}$.

Orbital and palpebral changes attributed to the use of bimatoprost like deep superior lid sulci, enophthalmos and bilateral dermatochalasis have been reported with greater frequency over the last years. Partial or complete relief of symptoms was reported in patients after 3 to 6 months of suspending bimatoprost ${ }^{[9,10]}$.

The adipose metabolism is regulated by hormones, such as insulin, catecholamine, natriuretic peptides, and other components like cytokines, adenosine and prostaglandin. ${ }^{[11]}$ The activation of prostanoid receptors has been associated with the inhibition of the differentiation of preadipocytes, blocking the expression of specific genes of adipocytes and the accumulation of fat ${ }^{[12,13]}$.

The increase of the palpebral fissure in patients who are chronic users of bimatoprost and other prostaglandin analogs might result from the stimulation of the Mueller muscle by prostamides, which probably contributes to the relaxation and contraction of the smooth muscle cell[9].

The objective of this study is to evaluate in experimental animals the changes of the palpebral fissure and the orbital volume after the orbital administration of bimatoprost $0.03 \%$.

\section{Methods}

This study was approved by the Ethics Committee in Animal Experimentation of the Faculty of Medicine ABC (FMABC). Thirty seven male Wistar rats (Rattus norvegicus albinus) were used, weighing approximately 400 grams, provided and kept by the central laboratory animal house of FMABC. The number of animals was defined in association with the Ethics Committee in Animal Experimentation of FMABC and it was enough to development of the study and statistical analysis. The number of animals required for this comparative study also influenced the decision about which experimental model would be used. The animals were divided into seven groups:

Group 1 (G1): the rats $(\mathrm{n}=05)$ were kept for four weeks receiving an upper temporal periocular injection of $4.8 \mu \mathrm{g}$ of bimatoprost $0.03 \%$ weekly in the right eye socket;

Group 2 (G2): the rats ( $\mathrm{n}=06)$ were kept for eight weeks receiving an upper temporal periocular injection of $4.8 \mu \mathrm{g}$ of

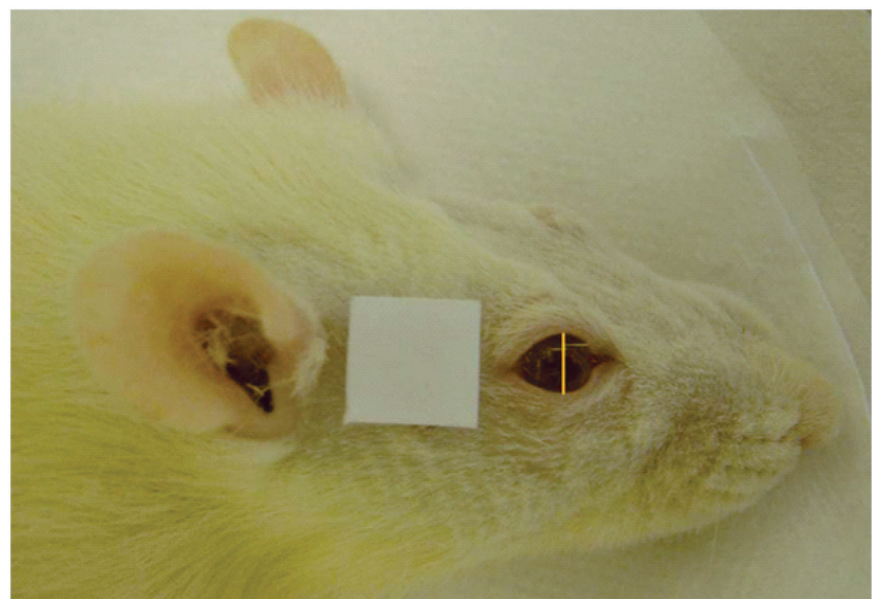

Figure 1: Right profile with the presence of a square label $10 \mathrm{~mm} x$ $10 \mathrm{~mm}$ in the periocular region; this label was used to obtain a standard measurement in the calculation of bilateral vertical eyelid fissure (vertical orange line) by computer analysis (ImageJ)

bimatoprost $0.03 \%$ weekly in the right eye socket;

- Group 3 (G3): the rats $(\mathrm{n}=05)$ were kept for twelve weeks receiving an upper temporal periocular injection of $4.8 \mu \mathrm{g}$ of bimatoprost $0.03 \%$ weekly in the right eye socket;

- Group 4 (G4): the rats (n=03) were kept for sixteen weeks receiving an upper temporal periocular injection of $4.8 \mu \mathrm{g}$ of bimatoprost $0.03 \%$ weekly in the right eye socket during the first twelve weeks. During the last four weeks no injections were given;

Group 5 (G5): the rats $(\mathrm{n}=06)$ were kept for twenty weeks receiving an upper temporal periocular injection of $4.8 \mu \mathrm{g}$ of bimatoprost 0.03 weekly in the right eye socket during the first twelve weeks and during the last eight weeks no injections were given;

Group 6 (G6): the rats $(\mathrm{n}=06)$ were kept for 24 weeks receiving an upper temporal periocular injection of $4.8 \mu \mathrm{g}$ of bimatoprost 0.03 weekly in the right eye socket during the first twelve weeks and during the last twelve week no injections were given;

Control Group (G7): the rats (n=06) were kept for four weeks receiving an upper temporal periocular injection of saline solution weekly in the right eye socket. The injections were given in the same volume as the other injections given to the animals of the other study groups.

The animals were fed with a normal commercial diet and water "ad libitum". Artificial lighting was used to guarantee light and dark cycles of twelve hours each and the average temperature was kept at $24^{\circ} \mathrm{C}$.

For the application of injections, the animals were given anesthesia using a mixture of xylazine $(5 \mathrm{mg} / \mathrm{kg})$ and ketamine $(10 \mathrm{mg} / \mathrm{kg})$ which was administered via intraperitoneal ${ }^{[14]}$. After anesthetic induction, antisepsis of eyelids was performed with iodine alcohol and an upper temporal periocular injection of bimatoprost $0.03 \%$ was given in the right eye socket ( $4.8 \mu \mathrm{g}$ ( 7 commercial drops) /eye socket /week).

After their relative period of injections for each group, the animals were put down by inhalation of carbon dioxide $(\mathrm{CO} 2)$ and, immediately following, were photographed with a Sony Cyber-shot DSC-W370 digital camera with 14.1 megapixels. The 
animals were photographed from a left and right profile position with a square label of a given size $(10 \mathrm{~mm} \times 10 \mathrm{~mm})$ around the periocular region. This label was used to help gain a standard measure when calculating the vertical bilateral palpebral fissure of each animal. This calculation was done on the images using a computerized processing with the program ImageJ (figure 1).

After taking the photographs, the animals were subjected to bilateral orbital exenteration with the help of a surgical microscope. The exenterated orbital tissue was then macroscopically analyzed (coloration and consistency) and, after removal of both upper and lower lids, the orbital volume of all the animals was calculated by the water displacement method (Archimedes' principle). The piece removed entirely with all the orbital tissue was immersed into a graduated cylinder (Vidrolex ${ }^{\circledR}$ ) with $10 \mathrm{ml}$ of saline solution at room temperature and the volume was calculated by evaluating the displacement of the water column.

The descriptive analysis of data was done with the help of

Table 1

Descriptive analysis of the orbital volumes of all study groups

\begin{tabular}{|c|c|c|c|c|c|c|c|c|c|}
\hline \multicolumn{10}{|c|}{ Orbital volume (ml) } \\
\hline \multirow[t]{2}{*}{ Group } & \multirow[t]{2}{*}{ Side } & \multirow[t]{2}{*}{$\mathbf{N}$} & \multirow[t]{2}{*}{ Mean } & \multirow{2}{*}{$\begin{array}{l}\text { Standard } \\
\text { Deviation }\end{array}$} & \multicolumn{2}{|c|}{ CI 95\% } & \multirow[t]{2}{*}{ Minimum } & \multirow[t]{2}{*}{ Average } & \multirow[t]{2}{*}{ Maximum } \\
\hline & & & & & $\mathbf{L L}$ & $\mathbf{U L}$ & & & \\
\hline \multirow[t]{2}{*}{ G1 } & $\mathbf{R}$ & 5 & 0.50 & 0.07 & 0.41 & 0.59 & 0.40 & 0.50 & 0.60 \\
\hline & $\mathbf{L}$ & 5 & 0.58 & 0.04 & 0.52 & 0.64 & 0.50 & 0.60 & 0.60 \\
\hline \multirow[t]{2}{*}{ G2 } & $\mathbf{R}$ & 6 & 0.57 & 0.05 & 0.51 & 0.62 & 0.50 & 0.60 & 0.60 \\
\hline & $\mathbf{L}$ & 6 & 0.62 & 0.08 & 0.54 & 0.70 & 0.50 & 0.60 & 0.70 \\
\hline \multirow[t]{2}{*}{ G3 } & $\mathbf{R}$ & 5 & 0.46 & 0.05 & 0.39 & 0.53 & 0.40 & 0.50 & 0.50 \\
\hline & $\mathbf{L}$ & 5 & 0.58 & 0.08 & 0.48 & 0.68 & 0.50 & 0.60 & 0.70 \\
\hline \multirow[t]{2}{*}{ G4 } & $\mathbf{R}$ & 3 & 0.50 & 0.00 & & & 0.50 & 0.50 & 0.50 \\
\hline & $\mathbf{L}$ & 3 & 0.57 & 0.06 & 0.42 & 0.71 & 0.50 & 0.60 & 0.60 \\
\hline \multirow[t]{2}{*}{ G5 } & $\mathbf{R}$ & 6 & 0.58 & 0.04 & 0.54 & 0.63 & 0.50 & 0.60 & 0.60 \\
\hline & $\mathbf{L}$ & 6 & 0.55 & 0.08 & 0.46 & 0.64 & 0.40 & 0.60 & 0.60 \\
\hline \multirow[t]{2}{*}{ G6 } & $\mathbf{R}$ & 6 & 0.58 & 0.04 & 0.54 & 0.63 & 0.50 & 0.60 & 0.60 \\
\hline & $\mathbf{L}$ & 6 & $0 ., 58$ & 0.04 & 0.54 & 0.63 & 0.50 & 0.60 & 0.60 \\
\hline \multirow[t]{2}{*}{ G7 } & $\mathbf{R}$ & 6 & 0.55 & 0.05 & 0.49 & 0.61 & 0.50 & 0.55 & 0.60 \\
\hline & $\mathbf{L}$ & 6 & 0.57 & 0.05 & 0.51 & 0.62 & 0.50 & 0.60 & 0.60 \\
\hline
\end{tabular}

$\mathrm{N}=$ number of animals; CI 95\% $=95 \%$ Confidence Interval

Table 2

Descriptive analysis of vertical palpebral fissure measurements of all the study groups

\begin{tabular}{|c|c|c|c|c|c|c|c|c|}
\hline \multicolumn{9}{|c|}{ Vertical fissure (mm) } \\
\hline \multirow[t]{2}{*}{ Side } & \multirow[t]{2}{*}{$\mathbf{N}$} & \multirow[t]{2}{*}{ Mean } & \multirow{2}{*}{$\begin{array}{l}\text { Standard } \\
\text { Deviation }\end{array}$} & \multicolumn{2}{|c|}{ CI 95\% } & \multirow[t]{2}{*}{ Minimum } & \multirow[t]{2}{*}{ Average } & \multirow[t]{2}{*}{ Maximum } \\
\hline & & & & $\mathbf{L} \mathbf{L}$ & $\mathbf{U L}$ & & & \\
\hline $\mathbf{R}$ & 5 & 4.01 & 0.52 & 3.36 & 4.66 & 3.28 & 3.90 & 4.57 \\
\hline $\mathbf{L}$ & 5 & 3.96 & 0.52 & 3.32 & 4.61 & 3.23 & 3.83 & 4.48 \\
\hline $\mathbf{R}$ & 6 & 4.41 & 0.34 & 4.05 & 4.76 & 4.04 & 4.32 & 4.98 \\
\hline $\mathbf{L}$ & 6 & 4.13 & 0.16 & 3.96 & 4.30 & 3.93 & 4.08 & 4.36 \\
\hline $\mathbf{R}$ & 5 & 4.61 & 0.63 & 3.83 & 5.38 & 3.81 & 4.66 & 5.33 \\
\hline $\mathbf{L}$ & 5 & 4.17 & 0.73 & 3.27 & 5.07 & 3.22 & 4.08 & 5.21 \\
\hline $\mathbf{R}$ & 3 & 4.20 & 0.19 & 3.73 & 4.67 & 3.98 & 4.28 & 4.33 \\
\hline $\mathbf{L}$ & 3 & 4.03 & 0.26 & 3.38 & 4.68 & 3.77 & 4.03 & 4.29 \\
\hline $\mathbf{R}$ & 6 & 4.32 & 0.25 & 4.06 & 4.58 & 3.97 & 4.31 & 4.74 \\
\hline $\mathbf{L}$ & 6 & 4.25 & 0.22 & 4.01 & 4.48 & 3.93 & 4.22 & 4.60 \\
\hline $\mathbf{R}$ & 6 & 4.22 & 0.68 & 3.50 & 4.93 & 3.22 & 4.18 & 5.21 \\
\hline $\mathbf{L}$ & 6 & 4.18 & 0.69 & 3.46 & 4.90 & 3.21 & 4.14 & 5.22 \\
\hline $\mathbf{R}$ & 6 & 4.09 & 0.18 & 3.90 & 4.27 & 3.93 & 4.03 & 4.33 \\
\hline $\mathbf{L}$ & 6 & 4.07 & 0.17 & 3.89 & 4.25 & 3.90 & 4.02 & 4.29 \\
\hline
\end{tabular}

$\mathrm{N}=$ number of animals; CI 95\% = 95\% Confidence Interval 


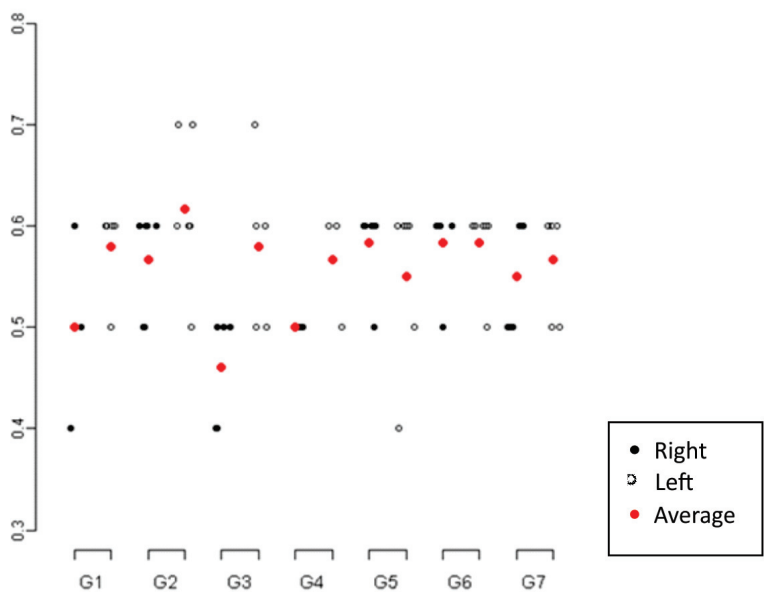

Figure 2: Descriptive analysis of the orbital volumes of all the study groups

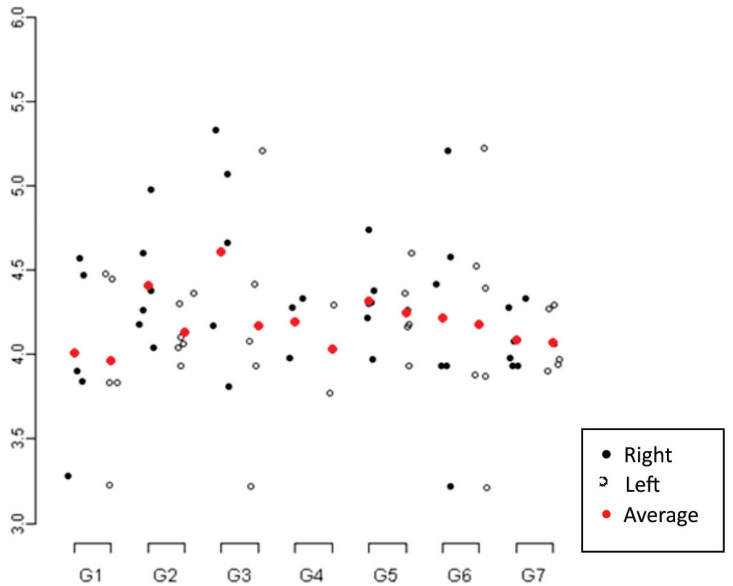

Figure 3: Descriptive analysis of vertical palpebral fissure measurements of all the study groups

Table 3

Comparative statistical analysis of orbital volumes between the study groups and the control group (G7) and between the left and right side of the control group (G7)

\begin{tabular}{|c|c|c|c|c|c|c|c|}
\hline \multicolumn{3}{|c|}{ Comparisons } & \multirow{2}{*}{$\begin{array}{l}\text { Approximate } \\
\text { difference }\end{array}$} & \multirow{2}{*}{$\begin{array}{l}\text { Standard } \\
\text { Error }\end{array}$} & \multicolumn{2}{|c|}{ CI 95\% } & \multirow[t]{2}{*}{ p-value } \\
\hline & & & & & $\mathbf{L L}$ & $\mathbf{U L}$ & \\
\hline G1ID & - & G7ID & -0.05 & 0.04 & -0.17 & 0.07 & 0.98 \\
\hline G1ID & - & $\mathrm{G} 7 \mid \mathrm{E}$ & -0.07 & 0.04 & -0.18 & 0.05 & 0.83 \\
\hline G1IE & - & G7|D & 0.03 & 0.04 & -0.09 & 0.15 & 0.99 \\
\hline G1IE & - & $\mathrm{G} 7 \mid \mathrm{E}$ & 0.01 & 0.04 & -0.10 & 0.13 & 0.99 \\
\hline G2ID & - & G7ID & 0.02 & 0.03 & -0.10 & 0.13 & 0.99 \\
\hline G2ID & - & $\mathrm{G} 7 \mid \mathrm{E}$ & 0.00 & 0.03 & -0.11 & 0.11 & 0.99 \\
\hline $\mathrm{G} 2 \mid \mathrm{E}$ & - & G7ID & 0.07 & 0.03 & -0.05 & 0.18 & 0.77 \\
\hline $\mathrm{G} 2 \mathrm{IE}$ & - & $\mathrm{G} 7 \mid \mathrm{E}$ & 0.05 & 0.03 & -0.06 & 0.16 & 0.97 \\
\hline G3|D & - & G7ID & -0.09 & 0.04 & -0.21 & 0.03 & 0.37 \\
\hline G3|D & - & $\mathrm{G} 7 \mid \mathrm{E}$ & -0.11 & 0.04 & -0.22 & 0.01 & 0.13 \\
\hline $\mathrm{G} 3 \mid \mathrm{E}$ & - & G7|D & 0.03 & 0.04 & -0.09 & 0.15 & 0.99 \\
\hline $\mathrm{G} 3 \mid \mathrm{E}$ & - & $\mathrm{G} 7 \mid \mathrm{E}$ & 0.01 & 0.04 & -0.10 & 0.13 & 0.99 \\
\hline G4ID & - & G7ID & -0.05 & 0.04 & -0.19 & 0.09 & 0.99 \\
\hline G4ID & - & $\mathrm{G} 7 \mid \mathrm{E}$ & -0.07 & 0.04 & -0.20 & 0.07 & 0.94 \\
\hline G4IE & - & G7ID & 0.02 & 0.04 & -0.12 & 0.15 & 0.99 \\
\hline $\mathrm{G} 4 \mid \mathrm{E}$ & - & $\mathrm{G}$ 7|E & 0.00 & 0.04 & -0.14 & 0.14 & 0.99 \\
\hline G5/D & - & G7ID & 0.03 & 0.03 & -0.08 & 0.15 & 0.99 \\
\hline G5ID & - & $\mathrm{G} 7 \mid \mathrm{E}$ & 0.02 & 0.03 & -0.10 & 0.13 & 0.99 \\
\hline G5IE & - & G7ID & 0.00 & 0.03 & -0.11 & 0.11 & 0.99 \\
\hline G5/E & - & $\mathrm{G}$ 7|E & -0.02 & 0.03 & -0.13 & 0.10 & 0.99 \\
\hline G6|D & - & G7|D & 0.03 & 0.03 & -0.08 & 0.15 & 0.99 \\
\hline G6|D & - & $\mathrm{G} 7 \mid \mathrm{E}$ & 0.02 & 0.03 & -0.10 & 0.13 & 0.99 \\
\hline G6|E & - & G7|D & 0.03 & 0.03 & -0.08 & 0.15 & 0.99 \\
\hline G6|E & - & $\mathrm{G}$ 7|E & 0.02 & 0.03 & -0.10 & 0.13 & 0.99 \\
\hline G7ID & - & $\mathrm{G}$ 기E & -0.02 & 0.03 & -0.11 & 008 & 0.99 \\
\hline
\end{tabular}

CI $95 \%=95 \%$ confidence interval; $\mathrm{LL}=$ lower limit; UL $=$ upper limit 
Table 4

\section{Comparative statistical analysis of vertical palpebral fissure measurements between the study groups and the control group (G7) and between the left and right side of the control group (G7)}

\begin{tabular}{|c|c|c|c|c|c|c|c|}
\hline \multirow{2}{*}{\multicolumn{3}{|c|}{ Comparisons }} & \multirow{3}{*}{$\begin{array}{c}\begin{array}{c}\text { Approximate } \\
\text { difference }\end{array} \\
-0.08\end{array}$} & \multirow{3}{*}{$\begin{array}{c}\text { Standard } \\
\text { error }\end{array}$} & \multicolumn{2}{|c|}{ CI $95 \%$} & \multirow{3}{*}{$\begin{array}{c}\text { p-value } \\
0.99\end{array}$} \\
\hline & & & & & \multirow{2}{*}{$\begin{array}{c}\mathbf{L L} \\
-0.95\end{array}$} & \multirow{2}{*}{$\frac{\mathbf{U L}}{0.80}$} & \\
\hline G1|D & - & G77D & & & & & \\
\hline G1|D & - & G7IE & -0.06 & 0.27 & -0.93 & 0.81 & 0.99 \\
\hline G1/E & - & G7/D & -0.12 & 0.27 & -1.00 & 0.75 & 0.99 \\
\hline G1/E & - & G7|E & -0.11 & 0.27 & -0.98 & 0.76 & 0.99 \\
\hline G2/D & - & G71D & 0.32 & 0.26 & -0.51 & 1.15 & 0.99 \\
\hline G2/D & - & G7/E & 0.34 & 0.26 & -0.50 & 1.17 & 0.98 \\
\hline G2|E & - & G71D & 0.04 & 0.26 & -0.79 & 0.87 & 0.99 \\
\hline G2IE & - & G7|E & 0.06 & 0.26 & -0.77 & 0.89 & 0.99 \\
\hline G3|D & - & G7/D & 0.52 & 0.27 & -0.35 & 1.39 & 0.72 \\
\hline G3|D & - & G7|E & 0.54 & 0.27 & -0.34 & 1.41 & 0.68 \\
\hline G3|E & - & $\mathrm{G} 7 \mathrm{D}$ & 0.08 & 0.27 & -0.79 & 0.96 & 0.99 \\
\hline G3|E & - & G7/E & 0.10 & 0.27 & -0.77 & 0.97 & 0.99 \\
\hline G4ID & - & G71D & 0.11 & 0.32 & -0.91 & 1.13 & 0.99 \\
\hline G4|D & - & G7|E & 0.13 & 0.32 & -0.89 & 1.14 & 0.99 \\
\hline G4|E & - & G7/D & -0.06 & 0.32 & -1.08 & 0.96 & 0.99 \\
\hline G4|E & - & G7|E & -0.04 & 0.32 & -1.06 & 0.98 & 0.99 \\
\hline G5ID & - & G7/D & 0.23 & 0.26 & -0.60 & 1.06 & 0.99 \\
\hline G5ID & - & G7|E & 0.25 & 0.26 & -0.58 & 1.08 & 0.99 \\
\hline G5|E & - & G71D & 0.16 & 0.26 & -0.67 & 0.99 & 0.99 \\
\hline G5IE & - & G71E & 0.18 & 0.26 & -0.65 & 1.01 & 0.99 \\
\hline G6|D & - & G71D & 0.13 & 0.26 & -0.70 & 0.96 & 0.99 \\
\hline G61D & - & $\mathrm{G} 7 \mathrm{E}$ & 0.14 & 0.26 & -0.69 & 0.97 & 0.99 \\
\hline G6|E & - & $\mathrm{G} 7 \mid \mathrm{D}$ & 0.09 & 0.26 & -0.74 & 0.92 & 0.99 \\
\hline G6IE & - & G7 7 E & 0.11 & 0.26 & -0.72 & 0.94 & 0.99 \\
\hline G7|D & - & $\mathrm{G} 7 \mathrm{E}$ & 0.02 & 0.06 & -0.18 & 0.21 & 0.99 \\
\hline
\end{tabular}

CI 95\% = 95\% confidence interval; LL = lower limit; UL = upper limit

R software ${ }^{[15]}$. The significance level adopted was $5 \%$.

The model of linear regression with mixed effects (random and fixed effects) was proposed for comparisons. The linear models of mixed effects are used in the analysis of data where the answers were grouped (more than one measurement for each individual) and the supposition of independence between observations in the same group is not adequate ${ }^{[15]}$. It is presupposed that the residuals of the models have a normal distribution with a 0 average and a constant variation $\sigma^{2}$. This procedure was performed with the software $\mathrm{R}$, using the name package. For the multiple comparisons by Tukey contrasts, a correction in values of $\mathrm{p}$ by the "single-step" method was used, making use of the multcomp package of the software $\mathrm{R}^{[15,16]}$.

\section{RESULTS}

Tables 1 and 2 respectively show the descriptive measures of the orbital volume and the vertical palpebral fissure of all the groups of the study. The descriptive data are also represented in figures 2 and 3 .

Tables 3 and 4 respectively show the result of the comparative statistical analysis of orbital volumes and the measurements of the vertical palpebral fissure among groups 1 ,
2, 3, 4, 5 and 6 and the control group.

In this comparative analysis it should be noted that there was no significant difference in the measurement of the vertical palpebral fissure $(p>0.68)$ and the orbital volume $(p>0.13)$ between the animals subjected to orbital injection with bimatoprost and the animals of the control group.

It is important to stress that there was no significant difference between the measurements of the right and left palpebral fissures of the control group after a comparative statistical analysis. This fact was also observed in the comparative analysis of the orbital volume of this group.

\section{Discussion}

The Wistar rats were the animal model chosen for this study because their orbital cavity and periocular anatomy are similar to human anatomy, although some particularities. Correlating human orbital anatomy with that of rats, the likeness should be noted in the conic form of the cavity and the disposition of fatty tissue ${ }^{(20,21)}$. In both, the adipose tissue fills the intraconal space (surrounded by four straight extraocular muscles), but also envelops and protects the optic nerve. The adipose tissue also fills the extra ${ }^{(19,20)}$. The physiology of eyelid movement of the rat 
and human are similar ${ }^{(20)}$

Correlating the human palpebral anatomy with that of rats, a likeness can be seen in the disposition of retractors of the upper $\operatorname{lid}^{[19,20]}$. In both, the elevating muscle of the upper eyelid originates in the orbital cone and inserts on the anterior and superior portion of the tarsal plate with an aspect of aponeurosis ${ }^{[19,20]}$. In human anatomy there is another retractor muscle of the upper eyelid, the Müeller muscle, of sympathetic innervation and which is present between the conjunctival fornix and the elevating muscle of the upper eyelid, with an insertion on the superior tarsal border ${ }^{[19]}$. In rats there is a superior tarsal muscle that extends between the anterior portion of the elevating muscle of the upper eyelid and the posterior portion of the superior tarsal ${ }^{[20]}$. Despite this similarity does not exist in the literature studies on the evaluation of the palpebral fissure, enophthalmos in orbital volume related to the use of bimatoprost in rats.

Also the effects of bimatoprost were analyzed as time of use in groups composed of animals with the same physical and environmental characteristics.

The palpebral and orbital changes attributed to the use of bimatoprost as an apparent enophthalmos and the increase of the palpebral fissure have been reported with greater frequency in the past years ${ }^{[4,9,10,17]}$

Literature on the matter reports that the apparent enophthalmos may result from the atrophy of preaponeurotic and orbital fat ${ }^{[10]}$. This hypothesis is based mainly on the pharmacological properties of bimatoprost, a synthetic prostaglandin analog F2Ü (PGF2 Ü) ${ }^{[2]}$. In the present experimental study the orbital injection of bimatoprost did not significantly change the orbital volume of animals, when compared with the control group.

The adipose metabolism is regulated by hormones, like insulin and catecholamine and by other components such as cytokines and prostaglandins ${ }^{[11]}$. The storage of lipids by mature adipocytes is regulated by insulin and by prostaglandins ${ }^{[11-13]}$. After the activation of prostanoid receptors, there is an inhibition of the differentiation of preadipocytes blocking the expression of specific genes of adipocytes and the accumation of fats ${ }^{[12,13]}$, Besides this, these receptors when activated inhibit the absorbtion of free fatty acids and the synthesis of triglycerides in adipocytes $^{[18]}$,

Pharmacokinetic studies in monkeys show that in a single instillation of bimatoprost $0.1 \%$ solution there was a concentration 2000 times greater of bimatoprost in the eyelids than in the aqueous humor and sixteen times greater in the iris and the ciliary body, which indicates a significant periorbital absorbtion of the medication ${ }^{[18]}$.

According to Peplinski and Albiani ${ }^{[9]}$, the increase of the palpebral fissure attributed to the use of bimatoprost and other prostaglandin analogs may result from the stimulation of the Mueller muscle by prostamides, which probably contributed to the relaxation and contraction of smooth muscular cells.

The intravenous administration of bimatoprost in monkeys for 17 weeks resulted in prominent periorbital sulci and the increase of the palpebral fissure. The same signs were observed six months after beginning to use bimatoprost solution in dosages of $0.03 \%$ twice a day or $0.1 \%$ once a day in the majority of the monkeys studied ${ }^{[18]}$. In this experimental study the orbital administration of bimatoprost did not significantly change the vertical palpebral fissure in animals, when compared to the control group.
All animals in this study were evaluated in identical conditions of temperature and anesthesic induction, so the analyzed measures were influenced only by the drug administration.

The purpose of this study was to evaluate in experimental animals the changes of the palpebral fissure and the orbital volume after the orbital administration of bimatoprost $0.03 \%$ and no significant difference in the measurements was observed. The results of this study suggest the hypothesis that the enophthalmos reported in patients using bimatoprost eye drops may be related to modification of collagen fibers, since a difference in orbital volume between the groups were not observed. This hypothesis proposes the necessity of microscopic evaluation of adipose tissue and collagen fibers present in the orbit of these animals. The authors of this study have already initiated another study to analyze this evaluation, as well as an immunohistochemical assay for the presence of neovascularization in different groups The findings in this study are considered only for the animal model used.

\section{Conclusion}

In this study there was no significant difference in the measurements of the vertical palpebral fissure and the orbital volume between the animals subjected to the orbital administration of bimatoprost and the animals of the control group.

\section{Acknowledgment}

I'd like to thanks Professor Olga Maria S de Toledo, Head of Department of Histology and Embriology at Faculdade de Medicina do ABC.

\section{RefERenCeS}

1. Cantor LB, WuDunn D, Cortes A, Hoop J, Knotts S. Ocular hypotensive efficacy of bimatoprost $0.03 \%$ and travoprost $0.004 \%$ in patients with glaucoma or ocular hypertension. Surv Ophthalmol. 2004;49 Suppl 1:S12-8.

2. Sharif NA, Kelly CR, Crider JY, Williams GW, Xu SX. Ocular hypotensive FP prostaglandin (PG) analogs: PG receptor subtype binding affinities and selectivities, and agonist potencies at $\mathrm{FP}$ and other PG receptors in cultured cells. J Ocul Pharmacol Ther. 2003;19(6):501-15.

3. Brubaker RF. Mechanism of action of bimatoprost (Lumigan). Surv Ophthalmol. 2001; 45 Suppl 4:S347-51.

4. Parrish RK, Palmberg P, Sheu WP,. A comparison of latanoprost, bimatoprost, and travoprost in patients with elevated intraocular pressure: a 12-week, randomized, masked-evaluator multicenter study. Am J Ophthalmol. 2003;135(5):688 -703.

5. DuBiner H, Cooke D, Dirks M, Stewart WC, VanDenburgh AM, Felix C. Efficacy and safety of bimatoprost in patients with elevated intraocular pressure: a 30-day comparison with latanoprost. Surv Ophthalmol. 2001; 45 Supl 4:S353-60.

6. Arcieri ES, Santana A, Rocha FN, Guapo GL, Costa VP. Blood-aqueous barrier changes after the use of prostaglandin analogues in patients with pseudophakia and aphakia: a 6-month randomized trial. Arch Ophthalmol. 2005;123(2):186-92.

7. Cohen JS, Gross RL, Cheetham JK, VanDenburgh AM, Bernstein P, Whitcup SM.Two-year doublemasked comparison of imatoprost with timolol in patients with glaucoma or ocular hypertension. Surv Ophthalmol. 2004;49(1):45-52. 
8. Centofanti M, Oddone F, Chimenti S, Tanga L, Citarella L, Manni G. Prevention of dermatologic side effects of bimatoprost $0.03 \%$ topical therapy. Am J Ophthalmol. 2006;142(6):1059-60.

9. Peplinski LS, Albiani SK. Deepening of lid sulcus from topical bimatoprost therapy. Optom Vis Sci. 2004;81(8):574-7.

10. Filippopoulos T, Paula JS, Torun N, Hatton MP, Pasquale LR, Grosskreutz CL. Periorbital changes associated with topical bimatoprost. Ophthal Plast Reconstr Surg. 2008;24(4):302-7.

11. Arner P. Human fat cell lipolysis: biochemistry, regulation and clinical role. Best Pract Res Clin Endocrinol Metab. 2005;19(4):471-82.

12. Miller CW, Casimir DA, Ntambi JM. The mechanism of inhibition of 3T3-L1 preadipocyte differentiation by prostaglandin F2alpha.Endocrinology. 1996;137(12):5641-50.

13. Serrero G, Lepak NM. Prostaglandin F2alpha receptor (FP receptor) agonists are potent adipose differentiation inhibitors for primary culture of adipocyte precursors in defined medium. Biochem Biophys Res Commun. 1997;233(1):200-2.

14. Danneman PI, Madnell TD. Evaluation of five agents/ methods for anesthesia of neonatal rats. Lab Anim Sci. 1997;47(4):386-95.

15. R Core Team. R: A language and environment for statistical computing. R Foundation for Statistical Computing, Vienna, Austria. Institute for Statistics and Mathematica; 2012. [cited 2014 Jul 20]. Available from:http://www.R-project.org/
16. Schall, R. Estimation in generalized linear models with random effects. Biometrika. 1991;78(4): 719-27.

17. Yam JC, Yuen NS, Chan CW. Bilateral deepening of upper lid sulcus from topical bimatoprost therapy. J Ocul Pharmacol Ther. 2009;25(4):471-2.

18. Woodward DF, Krauss AH, Chen J, Liang Y, Li C, Protzman $\mathrm{CE}$, Bogardus A, et al. Pharmacological characterization of a novel antiglaucoma agent, Bimatoprost. J Pharmacol Exp Ther. 2003;305(2):772-85.

19. Gentry LR. Anatomy of the orbit. Neuroimaging Clin N Am. 1998;8(1):171-94.

20. Felder E, Bogdanovich S, Rubinstein NA, Khurana TS. Structural details of rat extraocular muscles and three-dimensional reconstruction of the rat inferior rectus muscle and muscle-pulley interface. Vision Res. 2005;45(15):1945-55.

\section{Autor correspondente}

Nilson Lopes da Fonseca Junior

Av. Ibirapuera, no 2907 - conj. 1601 - Moema

CEP 04029-200 São Paulo (SP), Brazil

Fax: (11) 5041-4716

E-mail: lopesdafonseca@uol.com.br 